\title{
Cold Climate Winegrape Cultivar Sensitivity to Sulfur in the Northern Great Plains Region of the United States
}

\author{
Nagehan D. Köycü ${ }^{1}$, John E. Stenger ${ }^{2}$, \\ and Harlene M. Hatterman-Valenti ${ }^{2,3}$
}

\begin{abstract}
AdDitional INDEX wORDs. grapevine, leaf necrosis
SUMMARY. Elemental sulfur is commonly applied for powdery mildew (Erysiphe necator) protection on winegrape (Vitis sp.). The product may be used in a diversified, integrated disease management system to help prevent fungicide resistance to products with other modes of action. Additionally, sulfur may be used as a control option in organic systems. Applications of sulfur have been known to cause phytotoxic injury to susceptible winegrape cultivars, particularly those stemming from fox grape (Vitis labrusca) parentage. To improve recommendations to producers in the northern Great Plains region of the United States, a comparison of injury incidence and severity, as well as effects on yield characteristics was undertaken for 13 regional cultivars exposed to three sulfur rates $(0,2.4$, and $4.8 \mathrm{lb} /$ acre a.i.) at a North Dakota State University Research Station near Absaraka, ND. Overall, four cultivars (Bluebell, Baltica, Sabrevois, and King of the North) of the 13 cultivars tested showed phytotoxic symptoms. Injury severity and incidence of these cultivars differed between years and across rates. 'Bluebell' showed consistent and severe sulfur injury symptoms. Injury to the other three susceptible cultivars tended to vary by the given environment, with King of the North generally showing the lowest injury response. Injury symptoms were not found to be associated with the overall yield or cluster weight. Results suggest that alternative spray programs that exclude sulfur-based fungicides should be recommended for 'Bluebell', 'Baltica', 'Sabrevois', and 'King of the North', whereas sulfur-based fungicides may be applied to 'Alpenglow', 'ES 12-6-18', 'Frontenac', 'Frontenac Gris', 'La Crescent', 'Marquette', 'Somerset Seedless', 'St. Croix', and 'Valiant'. Observations on fruit ripening in 2014 suggest that future research is needed to determine if a reduction of fruit quality may occur in some seasons with repeated sulfur applications or with successive annual sulfur applications for susceptible cultivars if used in an organic production system.
\end{abstract}

$\mathrm{E}$ lemental sulfur is a commonly applied, effective powdery mildew control strategy in vineyards dating back two centuries (Forsyth, 1802). Bordelon et al. (2016) recommended a diverse and integrated management system for the control of powdery mildew. Such diversified approaches to powdery mildew management may reduce the risk of causal organisms developing resistance to some fungicides (Erickson and Wilcox, 1997). Elemental sulfur is also commonly used to control powdery mildew in organic production

We thank Collin Auwarter for his assistance with the spray applications.

${ }^{1}$ Department of Plant Protection, Namik Kemal University, 59030 Tekirdag, Turkey

${ }^{2}$ Department of Plant Sciences, North Dakota State University, P.O. Box 6050, Dept. 7670, Fargo, ND 58108-6050

${ }^{3}$ Corresponding author. E-mail: h.hatterman.valenti@ ndsu.edu.

doi: 10.21273/HORTTECH03638-16 systems because it works relatively well under low inoculum conditions early in the season and will help to reduce applications of more effective but more resistance-prone material later in the season during peak disease infection (Savocchia et al., 2011; Smith et al., 2014). When applied to tolerant vines, sulfur is a relatively inexpensive and effective complement to other fungicides for effective control and prevention of resistance (Bordelon et al., 2016). Additionally, early applications of micronized sulfur have been recommended before the application of other fungicides (Smith et al., 2014).

Despite its historic usage, grape cultivars have responded differently when sprayed with sulfur (Shertz et al., 1980). Sulfur intolerant cultivars are generally fox grape derived; e.g., Concord (Bordelon et al., 2016). Many of the cultivars grown in the upper midwest and northern Great Plains regions of the United States have fox grape in their lineage; thus, they may exhibit sulfur phytotoxicity symptoms, but have not been tested to identify sulfur sensitivities or tolerances. With the increase in grape production in the upper midwest and northern Great Plains regions of the United States, more information on best management practices is needed for cultivation under these relatively new conditions and with nontraditional grapevine cultivars (HattermanValenti et al., 2016).

If left uncontrolled, powdery mildew has been shown to cause premature leaf drop, stop the growth of berry epidermal tissue, reduce the rate of berry ripening, and slow periderm development (Gadoury et al., 2001, 2012). Such reductions in periderm development have been noted to decrease hardiness (Wolpert and Howell, 1986). These effects may be amplified in a region such as the northern Great Plains where short season length is inherently a limiting factor in production (HattermanValenti et al., 2016). The following study was conducted to evaluate micronized sulfur phytotoxicity on winegrape cultivars commonly grown in the northern portion of the United States.

\section{Materials and methods}

EXPERIMENTAL DESIGN. Treatments were applied to an experimental vineyard at a North Dakota State University Experimental Station near

\begin{tabular}{llll}
\hline $\begin{array}{l}\text { Units } \\
\begin{array}{l}\text { To convert U.S. to SI, } \\
\text { multiply by }\end{array}\end{array}$ & U.S. unit & SI unit & $\begin{array}{l}\text { To convert SI to U.S., } \\
\text { multiply by }\end{array}$ \\
\hline 0.3048 & $\mathrm{ft}$ & $\mathrm{m}$ & 3.2808 \\
25.4 & inch $(\mathrm{es})$ & $\mathrm{mm}$ & 0.0394 \\
0.4536 & $\mathrm{lb}$ & $\mathrm{kg}$ & 2.2046 \\
1.1209 & $\mathrm{lb} / \mathrm{acre}$ & $\mathrm{kg} \cdot \mathrm{ha}^{-1}$ & 0.8922 \\
1.6093 & $\mathrm{mph}$ & $\mathrm{km} \cdot \mathrm{h}^{-1}$ & 0.6214 \\
28.3495 & $\mathrm{Oz}$ & $\mathrm{g}$ & 0.0353 \\
$\left({ }^{\circ} \mathrm{F}-32\right) \div 1.8$ & ${ }^{\circ} \mathrm{F}$ & ${ }^{\circ} \mathrm{C}$ & $\left({ }^{\circ} \mathrm{C} \times 1.8\right)+32$
\end{tabular}


Absaraka, ND (lat. $46.991385^{\circ} \mathrm{N}$, long. $97.353922^{\circ} \mathrm{W}$ ) in 2013 and 2014. The test vineyard consisted of rows oriented north to south with $8 \mathrm{ft}$ between vines and a row spacing of $10 \mathrm{ft}$. All vines were trained to a highwire bilateral cordon trellis system and spurred pruned using the balanced pruning method (Dami et al., 2005). A $3-\mathrm{ft}$ herbicide strip was maintained under the trellis and a permanent creeping red fescue (Festuca rubra) strip was between rows. The vineyard was divided into four replicates. Within each replicate, cultivar was randomly assigned to a whole plot and consisted of four adjacent vines for the 13 tested cultivars (Table 1). Within each whole plot, individual subplot vines received randomly assigned rates of sulfur. Two of the four subplot vines acted as controls receiving no sulfur, whereas the remaining two vines received micronized wettable sulfur (Bonide Products, Oriskany, NY) at recommended rates of either 2.4 or $4.8 \mathrm{lb} /$ acre a.i., respectively. Sulfur was applied using a backpack blower/mister (model no. 450; Solo, Newport News, VA) on 19 July 2013 and 17 July 2014 when berries were generally pea-size ( $7 \mathrm{~mm}$ diameter). Half of the spray solution for a particular vine was applied to the west-facing canopy, with the remaining amount applied to the east-facing canopy. Applications were made in the morning with less than 2-mph wind. Care was taken with the directed application to prevent the spray from contaminating adjacent plants within a row and adjacent rows. No other fungicides applications were made to the grapes as powdery mildew was only occasionally observed on 'Baltica' and 'Valiant' grapes in previous years, but was not present at the time of application. Since producers in more arid regions such as North Dakota have reduced fungicide spray programs compared with northeastern states or try to produce grapes organically, the same plants were sprayed the second year to begin to address the effect of annual sulfur applications.

Sulfur Phyтотохісіту. Visible foliar injury symptoms of leaf reddening, chlorosis, necrotic spots, leaf tip necrosis, and leaf margin necrosis were recorded from 50 leaves randomly selected from both sides of

Table 1. Winegrape cultivars evaluated for sulfur sensitivity and their origin.

\begin{tabular}{lll}
\hline Cultivar & \multicolumn{1}{c}{ Origin } & \multicolumn{1}{c}{ Reference } \\
\hline Alpenglow & Elmer Swenson, Wisconsin & Smiley et al. (2008) \\
Bluebell & University of Minnesota, 1944 & Smiley et al. (2008) \\
Baltica & A.K. Bous, Russia, 1950-60 & Rätsep et al. (2014) \\
ES 12-6-18 & Elmer Swenson, Wisconsin & Camper (2016) \\
Frontenac & University of Minnesota, 1996 & Luby and Hemstad (2004a) \\
Frontenac Gris & University of Minnesota, 2004 & Luby and Hemstad (2004a) \\
King of the North & Unknown & Smiley et al. (2008) \\
La Crescent & University of Minnesota, 2004 & Luby and Hemstad (2004b) \\
Marquette & University of Minnesota, 2008 & Hemstad and Luby (2008) \\
Sabrevois & Elmer Swenson, Wisconsin & Smiley et al. (2008) \\
Somerset seedless & Elmer Swenson, Wisconsin & Smiley et al. (2008) \\
St. Croix & Elmer Swenson, Wisconsin, 1982 & Swenson (1982) \\
Valiant & South Dakota State University & Smiley et al. (2008) \\
\hline
\end{tabular}

the canopy. Areas toward the end of a cordon were avoided to reduce the risk of evaluating leaves that had received spray drift. Initial visual leaf evaluations occurred $\approx 14 \mathrm{~d}$ after the application. Injury incidence was measured using the formula:

Injury incidence $(\%)$

number of injured leaves $\times 100$

total number of leaves(injured and healthy)

Injury severity used a European and Mediterranean Plant Protection Organization (EPPO) rating scale of 0 to 10 where $0=$ no foliar injury symptoms and $10=$ leaf had all of the above described injury symptoms and no green tissue (EPPO, 2008). The injury severity was measured using the formula:

$$
\operatorname{Injury~severity}(\%)=\frac{\Sigma(n \times v) \times 100}{\mathrm{~N}}
$$

where $\mathrm{n}=$ number of injured leaves in each severity category, and $v=$ percentage values of each severity category, and $\mathrm{N}=$ total number of leaves observed.

Yield Characteristics. Yield (kilograms per plant) and cluster weight (grams per cluster) at the time of harvest from 2011-14 were used to evaluate potential effects of sulfur application on overall vine production. Yield was evaluated as the total weight obtained from each vine at the time of harvest and cluster weight was evaluated as this total harvest yield divided by the number of clusters harvested. Time of harvest of each cultivar was determined separately based on fruit maturity using percentage soluble solids, $\mathrm{pH}$, titratable acids, and fruit condition.

Statistical analyses. Sulfur injury data were evaluated as a randomized complete block design with a split-plot arrangement and four replications; 13 whole-plot cultivars and three subplot rates evaluated over years as a split-plot-in-time using the mixed procedure of SAS statistical software (version 9.4; SAS Institute, Cary, NC). Cultivars, sulfur rates, and years were treated as fixed effects, while replications were considered random. Percentage incidence and severity were arcsin transformed to normalize the data before analysis and then inversely transformed for the presented means.

Treatment effects on yield and cluster weight were investigated through comparisons among presulfur application and application years. As treatments were statically applied to the same vines throughout the study, treatment effects may be confounded with preapplication vine and plot effects, increasing the risk of false positive detection. To account for production differences among individual plants before the application of treatments, a variable was created to group preapplication (2011 and 2012) and application (2013 and 2014) years. Significant interaction among sulfur treatments and the created variable would signify that vine responses to sulfur treatment application differed from that expected from the sums of the main effects. This would indicate a change in the relative responses of vines following respective sulfur treatment applications when compared with the relationships among 
vines before treatment application. Similar to the analysis of sulfur injury, the plot was arranged as a randomized complete block design with a split-plot arrangement with four replications and was evaluated across application groups as a repeated measure. Application groups, sulfur rate, and cultivars were treated as fixed effects, whereas replications and years were treated as random effects. Only interactions involving application groups and sulfur treatments were investigated when they were found to be significant.

\section{Results and discussion}

Sulfur PHYTOTOXICITy. In both injury incidence and severity percentages, a cultivar-by-rate-by-year interaction was detected $(P<0.0001)$ as shown in Figs. 1 and 2. Through tests of simple effects, cultivars were found to vary in symptomology within each year only under sulfur application rates of 2.4 and $4.8 \mathrm{lb} /$ acre. Tests of simple effects on the variation of sulfur rate within each cultivar revealed that four (Bluebell, Baltica, King of the North, and Sabrevois) of the 13 cultivars showed sensitivity to sulfur applications and did so in both tested seasons. All other tested cultivars (Alpenglow, ES 12-6-18, Frontenac, Frontenac Gris, La Crescent, Marquette, Somerset Seedless, St. Croix, and Valiant) did not differ from untreated vines in incidence or severity under either application rate during either year.

Percent incidence varied with year for all sensitive cultivars. Injury incidence did not differ among the two applied rates, 2.4 and $4.8 \mathrm{lb} /$ acre, in 2013 for any susceptible cultivar; however, differences among these rates were observed within all susceptible cultivars except Bluebell in 2014 (Fig. 1). Of the susceptible cultivars, Bluebell and King of the North had similar injury severity over the two seasons (Fig. 2). All other sensitive cultivars differed in injury severity at both applied rates between the two application seasons. Only 'Baltica', in 2013, was found to have a similar injury severity following a doubling of the sulfur application rate from 2.4 to $4.8 \mathrm{lb} /$ acre. In all other year-by-cultivar combinations, application of sulfur at $4.8 \mathrm{lb} /$ acre resulted in increased injury severity over $2.4 \mathrm{lb} /$ acre.

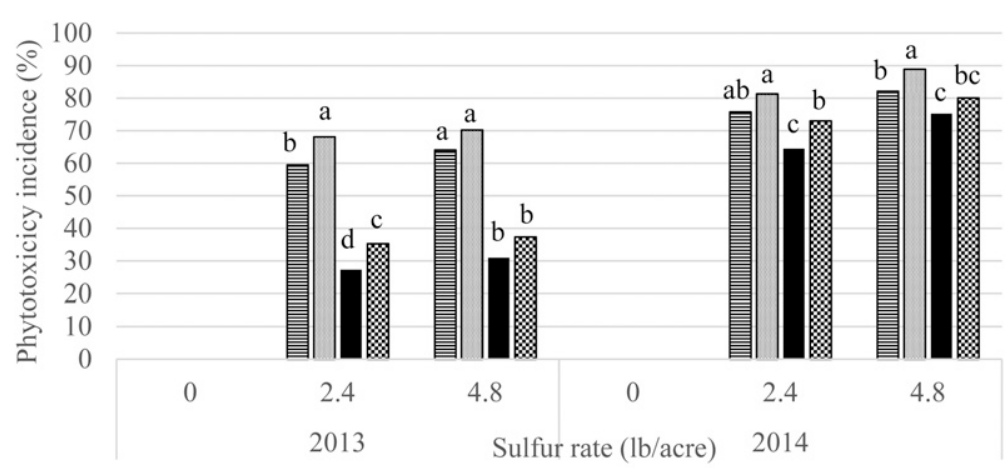

目Bluebell $\square$ Baltica $\square$ King of the North $\otimes$ Sabrevois

Fig. 1. Interaction among year, winegrape cultivar and sulfur application rate on phytotoxicity percent incidence 2013 and 2014. Data were arcsin transformed for before analysis and presented as untransformed means. Cultivars having the same letter within the same rate and year are not different at $\alpha=0.05$ by pairwise $t$ tests. Nine of the 13 tested cultivars were omitted as mean incidence was less than $1 \%$. Phytotoxicity incidence for omitted cultivars were not different from all other cultivars when sulfur was not applied, were lower than all sensitive cultivars, and were not different from one another at sulfur rates of 2.4 and $4.8 \mathrm{lb}$ a.i./acre; $1 \mathrm{lb} /$ acre $=1.1209 \mathrm{~kg} \cdot \mathrm{ha}^{-1}$.

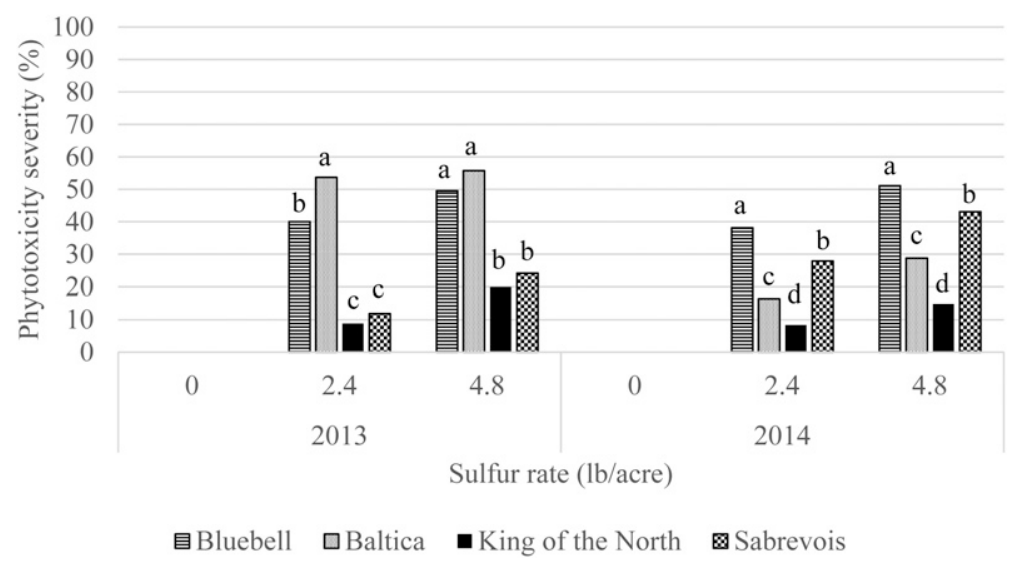

Fig. 2. Interaction among year, winegrape cultivar and sulfur application rate on phytotoxicity severity in 2013 and 2014 . Cultivars having the same letter within the same rate and year are not different at $\alpha=0.05$ by pairwise $t$ tests. Nine of the 13 tested cultivars were omitted as mean severity was less than $1 \%$. Phytotoxicity severity for omitted cultivars were not different from all cultivars when sulfur was not applied, were significantly lower than all sensitive cultivars, and were not different from one another at sulfur rates of 2.4 and $4.8 \mathrm{lb} / \mathrm{acre} ; 1 \mathrm{lb} / \mathrm{acre}=$ $1.1209 \mathrm{~kg} \cdot \mathrm{ha}^{-1}$.

The rankings among susceptible cultivars in injury incidence tended to be similar in both years, with less variability among cultivars in 2014 relative to 2013 (Fig. 1). However, cultivars were more variable in the severity of symptoms (Fig. 2). Overall, 'Baltica' had among the highest incidence of injury in both seasons, whereas having among the highest in severity in 2013 with reduced severity in 2014, respectively. All remaining cultivars maintained similar rankings across the two seasons in the severity of symptoms. Of the four sensitive cultivars, King of the North was consistently among the least affected in either incidence or severity across years and applied rates. In either year, 'Bluebell' had greater severity in injury than either 'Sabrevois' or 'King of the North', whereas 'Sabrevois' had higher injury severity than 'King of the North' in 2014, but was similar in 2013. It is readily known that sulfur can cause injury to foliage and 
fruit when applied just before or on days when the temperature exceeds $38{ }^{\circ} \mathrm{C}$ (Sall et al., 1983). Although the maximum air temperature did not reach $38^{\circ} \mathrm{C}$ in either year (Fig. 3), the temperature was 33 and $34^{\circ} \mathrm{C}$ the $2 \mathrm{~d}$ before the sulfur application in 2013 . This increased temperature may have contributed to higher injury severity with 'Baltica' and differences in severity rankings among the sensitive cultivars across the tested years.

The current study identified four cultivars commonly grown in the northern Great Plains Region to be sensitive to sulfur injury upon application under field conditions. The cultivars most sensitive included
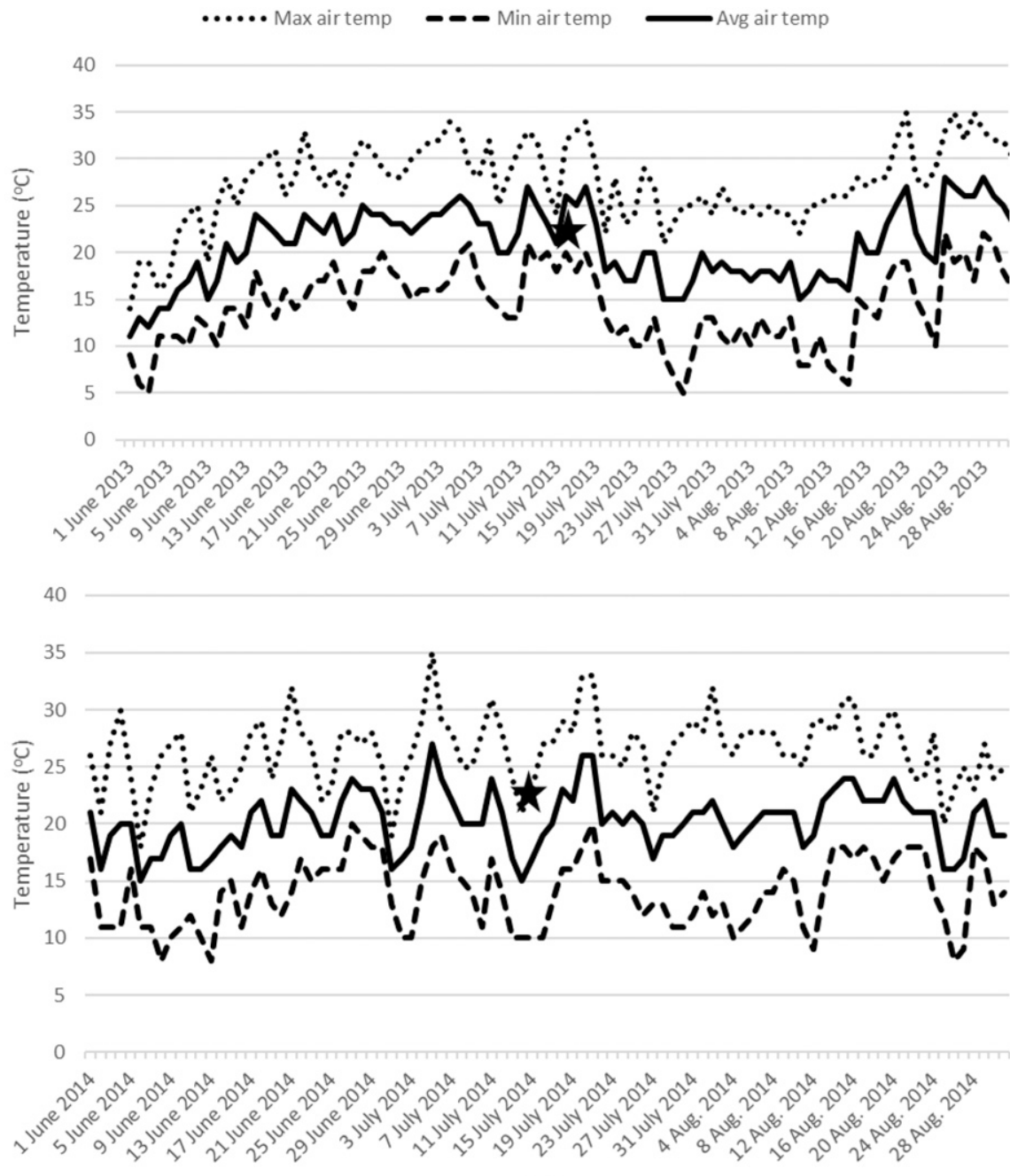

Sulfur application

Date

Fig. 3. Minimum, maximum, and average daily air temperatures from weather station near Absaraka, ND for the months of June, July, and August with the star signifying the day sulfur was applied to the winegrape cultivars; $\left({ }^{\circ} \mathrm{C} \times 1.8\right)+32={ }^{\circ} \mathrm{F}$.

Baltica and Bluebell followed by Sabrevois and then King of the North. Additionally, though tested rates were among lower recommended rates, the current study provides support for previously reported sensitivities of grapevines in the Midwest Fruit Pest Management Guide (Bordelon et al., 2016), in which 'Frontenac' and 'Frontenac Gris', were tolerant to sulfur, and provided additional information for ' $\mathrm{La}$ Crescent', 'Marquette', and 'St. Croix', which were listed as "?" for sulfur application tolerance. All four susceptible cultivars had lineages derived from the fox grape. However, not all fox grape derived cultivars grown in the region were susceptible to sulfur injury. Many cultivars and accessions from Swenson's (1982) breeding program were found to be sulfur tolerant (Alpenglow, ES 12-6-18, Somerset Seedless, and St. Croix), as well as the South Dakota State University release Valiant. Interestingly, opposing responses were found in the full-sibling cultivars St. Croix (tolerant) and Sabrevois (susceptible).

Yield CHARACTERISTICS. Vine yield and cluster weight were not impacted by sulfur application (yield, $P>\mathrm{F}=0.23$; cluster weight, $P>\mathrm{F}=$ 0.24 ), and only differed by year and cultivar combinations (Table 2.). Vine yield and cluster weight results suggested that the increase in yield and cluster weight was more likely to be related to increased vine age than treatments. Differences in fruit ripening were noted in 2014 where 'Bluebell' and, to a lesser degree, 'Baltica' were observed to have delayed onset of veraison following sulfur applications compared with the unsprayed controls, though data were not taken or analyzed. In addition, in many regions, multiple sulfur applications occur in a typical vineyard, thus, damage may be greater

Table 2. Winegrape vine yield and cluster weight effect from preapplication (2011 and 2012) to postapplication (2013 and 2014) years at three sulfur rates.

\begin{tabular}{|c|c|c|c|c|}
\hline \multirow{3}{*}{$\frac{\text { Sulfur rate }}{\text { lb/acre }}$} & \multicolumn{2}{|c|}{ 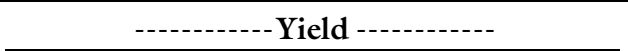 } & \multicolumn{2}{|c|}{---------Cluster wt-------- } \\
\hline & Preapplication & Postapplication & Preapplication & Postapplication \\
\hline & \multicolumn{2}{|c|}{$\left[\text { mean } \pm \mathrm{CI}^{\mathrm{z}}(\mathrm{kg} / \text { plant })\right]^{\mathrm{y}}$} & \multicolumn{2}{|c|}{$\left[\text { mean } \pm \mathrm{CI}^{\mathrm{z}}(\mathrm{g} / \text { cluster })\right]^{\mathrm{y}}$} \\
\hline 2.4 & $3.1 \pm 0.5$ & $3.0 \pm 0.5$ & $53.5 \pm 4.7$ & $65.4 \pm 4.9$ \\
\hline 4.8 & $2.8 \pm 0.5$ & $3.4 \pm 0.5$ & $49.6 \pm 4.8$ & $69.1 \pm 4.8$ \\
\hline
\end{tabular}

${ }^{\mathrm{z}} \mathrm{CI}$ at $\alpha=0.05$

${ }^{\mathrm{y}} 1 \mathrm{lb} / \mathrm{acre}=1.1209 \mathrm{~kg} \cdot \mathrm{ha}^{-1}, \mathrm{l} \mathrm{kg}=2.2046 \mathrm{lb}$, and $1 \mathrm{~g}=0.0353 \mathrm{oz}$ 
on some cultivars under commercial conditions. For these reasons, further evaluation on fruit quality parameters is advised to better reflect the overall impact on production and salability of fruit when multiple or successive annual sulfur applications are made as organic producers may be inclined to apply sulfur for powdery mildew control even though the cultivar is known to be sensitive to sulfur.

In conclusion, a single sulfur application demonstrated that many of the cold climate grapevines (' $\mathrm{Al}$ penglow', 'ES 12-6-18', 'Frontenac', 'Frontenac Gris', 'La Crescent', 'Marquette', 'Somerset Seedless', 'St. Croix', and 'Valiant') were tolerant to sulfur rates used in this study when maximum daily temperatures did not exceed $34{ }^{\circ} \mathrm{C}$. Although sulfur injury symptomology on sensitive grapevines ('Bluebell', 'Baltica', 'King of the North', and 'Sabrevois') did not impact the quantity of fruit produced, observations on fruit appearance suggest that future research is needed to determine if a reduction of fruit quality may occur in some seasons or with successive annual sulfur applications. Sulfur applications to the susceptible cultivars should be discouraged and other control measures should be explored while maintaining an integrated control strategy for powdery mildew.

\section{Literature cited}

Bordelon, B., J. Beckerman, R. Bessin, J. Strang, and R. Weinzierl. 2016. Midwest fruit pest management guide 2016. 17 Nov. 2016. <https://ag.purdue.edu/ hla/Hort/Documents/ID-465.pdf>.
Camper, C.R. 2016. Chateau stripmine. 17 Nov. 2016. <http://chateaustripmine. info/Breeders-/SwensonE.htm>.

Dami, I., B. Bordelon, D. Ferree, M. Brown, M. Ellis, R.N. Williams, and D. Doohan. 2005. Midwest grape production guide. Ohio State Univ. Ext. Publ. 919-05.

Erickson, E.O. and W.F. Wilcox. 1997. Distributions and sensitivities to three sterol demethylation inhibitor fungicides among populations of Uncinula necator sensitive and resistant to triadimefon. Phytopathology 87:784-791.

European and Mediterranean Plant Protection Organization. 2008. EPPO standards (PPl) - Efficacy evaluation of plant protection products. 17 Nov. 2016. <http://ppl.eppo.int/>.

Forsyth, W. 1802. A treatise on the culture and management of fruit-trees. Nichols and Son, London, UK.

Gadoury, D.M., L. Cadle-Davidson, W.F. Wilcox, I.B. Dry, R.C. Seem, and M.G. Milgroom. 2012. Grapevine powdery mildew (Erysiphe necator): A fascinating system for the study of the biology, ecology and epidemiology of an obligate biotroph. Mol. Plant Pathol. 13:1-16.

Gadoury, D.M., R.C. Seem, R.C. Pearson, and W.F. Wilcox. 2001. Effects of powdery mildew on vine growth, yield, and quality of Concord grapes. Plant Dis. 85:137140.

Hatterman-Valenti, H.M., C.P. Auwarter, and J.E. Stenger. 2016. Evaluation of coldhardy grape cultivars for North Dakota and the North Dakota State University germplasm enhancement project. Acta Hort. 1115:13-22.

Hemstad, P. and J. Luby. 2008. Grapevine plant named 'Marquette'. US PP12579 P3. U.S. Patent Trademark Office, Washington, DC.
Luby, J. and P. Hemstad. 2004a. Grape plant named 'Frontenac Gris'. US 20040237158 Pl. U.S. Patent Trademark Office, Washington, DC.

Luby, J. and P. Hemstad. 2004b. Grape plant named 'La Crescent'. US PP14617 P3. U.S. Patent Trademark Office, Washington, DC.

Rätsep, R., K. Karp, E. Vool, and T. Tõnutare. 2014. Effect of pruning time and method on hybrid grapevine (Vitis sp.) 'Hasanski Sladki' berry maturity in a cool climate conditions. Acta Sci. Pol. Hortorum Cultus 13:99-112.

Sall, M.A., J. Wrysinski, and F.J. Schick. 1983. Temperature-based sulfur applications to control grape powdery mildew. Calif. Agr. 37(7):4-5.

Savocchia, S., R. Mandel, P. Crisp, and E.S. Scott. 2011. Evaluation of 'alternative' materials to sulfur and synthetic fungicides for control of grapevine powdery mildew in a warm climate region of Australia. Austral. Plant Pathol. 40:20-27.

Shertz, R.D., W.J. Kender, and R.C. Musselman. 1980. Effects of ozone and sulfur dioxide on grapevines. Sci. Hort. 13:37-45.

Smiley, L., P. Domoto, G. Nonnecke, and W. Miller. 2008. Cold climate cultivars: A review of cold climate grape cultivars. Iowa State Univ. Ext., Ames.

Smith, R.J., L.J. Bettiga, and W.D. Gubler. 2014. Grape powdery mildew. 15 June 2016. <http://www.ipm.ucdavis.edu/>.

Swenson, E. 1982. Grapevine. US PP4928 P. U.S. Patent Trademark Office, Washington, DC.

Wolpert, J.A. and G.S. Howell. 1986. Cold acclimation of Concord grapevines III. Relationship between cold hardiness, tissue water content, and shoot maturation. Vitis 25:151-159. 